\title{
Synthesis of recycled cements using hydrothermally treated waste soda lime glass
}

\author{
Hidetoshi MIYAZAKI ${ }^{\dagger}$, Masaaki YOSHIKAWA, Daiki ATARASHI, Hidekazu TANAKA and Toshitaka OTA* \\ Interdisciplinary Graduate School of Science and Engineering, Shimane University, 1060 Nishikawatsu, Matsue 690-8504, Japan \\ *Ceramic Research Laboratory, Nagoya Institute of Technology, 10-6-29 Asahigaoka, Tajimi, Gifu 507-0071, Japan
}

\begin{abstract}
Waste soda lime glass powder was hydrothermally treated twice at $150^{\circ} \mathrm{C}$, and the resulting powder was mixed with $\mathrm{CaCO}_{3}$ powder in the weight ratio of $1: 3$ and heat-treated at $1450^{\circ} \mathrm{C}$. The resulting powder was identified as $\mathrm{Ca}_{3} \mathrm{SiO}_{5}$ as the main phase with small amounts of $\mathrm{Ca}_{3} \mathrm{Al}_{2} \mathrm{O}_{6}$, which are both common Portland cement sources. The elemental composition of the resulting cements was evaluated and all minor components $\left(\mathrm{Cl}, \mathrm{Na}, \mathrm{SO}_{3}\right.$, etc.) were found to be less than the JIS standard value for eco-cement. (C2017 The Ceramic Society of Japan. All rights reserved.
\end{abstract}

Key-words : Waste glass, Soda lime glass, Cement, Hydrothermal treatment

[Received October 17, 2016; Accepted November 11, 2016]

Only a small fraction of glass products such as glass bottles and building windows are recycled, and most glass products are discarded, totaling over 600 million tons per year in Japan. ${ }^{1)}$ The chemical composition of waste glass products is close to clay or sand; therefore, many investigations have been reported on the use of waste glass powder as a partial cement replacement. ${ }^{2)-4)}$ However, there are no reports of trying to apply the waste glass to recycled cement directly.

It has been reported that municipal waste incineration ashes can be converted into recycled cements, and such recycled cement is known as "eco-cement". 5),6) These eco-cements have been practically applied to buildings. ${ }^{7)}$ The chemical composition of an eco-cement is defined by a JIS standard. ${ }^{8)}$ In particular, the minor components of the eco-cement are severely restricted because they inhibit the hardening of raw cements during practical concrete formation. The minor components specified in the standard are $\mathrm{MgO}, \mathrm{SO}_{3}$, and total alkali metals and chlorides. The JIS standard is noted later in Table 1.

In our previous study, we converted soda-lime glass powders in the form of general waste glass to silicon dioxide raw materials using a hydrothermal process, and fabricated silicon oxynitride powders using the hydrothermally treated soda lime glass. ${ }^{9)}$ The $\mathrm{Na}$ in soda-lime glass can be removed by a hydrothermal process, ${ }^{9)}$ and hydrothermally treated soda-lime glass is thus expected to be used for the synthesis of recycled cements as a raw silicate material. In the present investigation, we report the synthesis of recycled cements using waste soda lime glasses. We then evaluate the chemical composition of the resulting cement and compare it with the eco-cement in the JIS standard.

$\mathrm{CaCO}_{3}$ (calcite, Wako, particle size $2-7 \mu \mathrm{m}$ ) and $\mathrm{SiO}_{2}$ (quartz, Kojundo, particle size $3-5 \mu \mathrm{m}$ ) powder were used as standard materials, and waste soda lime glass powder was used as the raw material for the synthesis of recycled cements. Soda lime glass was milled to a particle size of less than $10 \mu \mathrm{m}$. The ground particles were added to ion-exchanged water at a concentration of $5 \mathrm{~g} / \mathrm{L}$ and $100 \mathrm{~mL}$ of the suspension was hydrothermally treated twice at $150^{\circ} \mathrm{C}$ for $24 \mathrm{~h}$. A scanning electron microscopy (SEM)

\footnotetext{
Corresponding author: H. Miyazaki; E-mail: miya@riko.shimaneu.ac.jp
}

image of the resulting powder is shown in Fig. 1, from which the particle size of the hydrothermally treated powder can be seen to be $2-3 \mu \mathrm{m}$. Hereafter, we refer to this resulting powder as the post-treated glass powder. The $\mathrm{SiO}_{2}$ powder or post-treated glass powder was mixed with $\mathrm{CaCO}_{3}$ and milled (the mixing ratio is described in the results section), and the mixture was heat-treated at $1450^{\circ} \mathrm{C}$ for $20 \mathrm{~h}$.

The crystallographic structures of the powders were characterized using an X-ray diffractometer (XRD, Rigaku Miniflex) with $\mathrm{Cu} \mathrm{K} \alpha$ radiation $(30 \mathrm{kV}, 15 \mathrm{~mA})$. The microstructure of the powder was observed using SEM (JEOL JSM-6510). The elementary composition of the sample was evaluated using an X-ray fluorescence spectrometer (XRF, Rigaku ZSX PRIMUS).

Commercial $\mathrm{CaCO}_{3}$ and $\mathrm{SiO}_{2}$ powders were mixed in a molar ratio of $3: 1$ and the mixture was heat-treated at $1450^{\circ} \mathrm{C}$ for $20 \mathrm{~h}$. Figure 2 depicts the XRD pattern of the resulting powder, from which the powder can be assigned as $\mathrm{Ca}_{3} \mathrm{SiO}_{5}$ (C3S; JCPDS: 30301). The $\mathrm{C} 3 \mathrm{~S}$ production reaction did not proceed at heattreatment temperatures of less than $1450^{\circ} \mathrm{C}$ and heat-treatment times of $20 \mathrm{~h}$, so we employed $\mathrm{C} 3 \mathrm{~S}$ production reaction conditions of $1450^{\circ} \mathrm{C}$ for $20 \mathrm{~h}$.

$\mathrm{CaCO}_{3}$ powder and post-treated glass powder were mixed and milled in the weight ratio of $3: 1$, and the mixture was heat-treated at $1450^{\circ} \mathrm{C}$ for $20 \mathrm{~h}$. Figure 3 illustrates the XRD pattern of the resulting powder. The sample exhibits a main phase comprising C3S with small amounts of $\mathrm{Ca}_{3} \mathrm{Al}_{2} \mathrm{O}_{6}$ (C3A; JCPDS: 33-0251), where $\mathrm{C} 3 \mathrm{~A}$ is also one of the Portland cement compositions. The silicate source of soda lime glass includes silicon and aluminum; thus, the $\mathrm{C} 3 \mathrm{~S}$ and $\mathrm{C} 3 \mathrm{~A}$ phases appeared in the resulting powder. Other phases were not observed.

In order to confirm the microstructure of the resulting powder, SEM observation was carried out. Figure 4 presents the SEM image of the resulting powder. Most of the particles had a platelike shape, and the particles are assumed to be $\mathrm{C} 3 \mathrm{~S} .{ }^{10)}$ Bulk-like particles as a secondary phase were observed, and the particles are assumed to be $\mathrm{C} 3 \mathrm{~A} .{ }^{11)}$ These results agree well with the XRD results.

Elemental analysis was carried out for the resulting powder using the post-treated glass powder as a raw material, and the composition in terms of weight percent is shown in Table 1 . The 
Table 1. Mass \% of the composition of the JIS R5214-2009, the resulting powder and the representative commercial eco-cement (by Taiheiyo-cement) ${ }^{12)}$

\begin{tabular}{ccccccccccc}
\hline & $\mathrm{CaO}$ & $\mathrm{SiO}_{2}$ & $\mathrm{Al}_{2} \mathrm{O}_{3}$ & $\mathrm{Fe}_{2} \mathrm{O}_{3}$ & $\mathrm{SO}_{3}$ & $\mathrm{Cl}^{-}$ & $\mathrm{MgO}$ & $\mathrm{P}_{2} \mathrm{O}_{3}$ & $\begin{array}{c}\mathrm{Na}_{2} \mathrm{O} \\
(\mathrm{Alkali})\end{array}$ & ig.loss \\
\hline JIS & - & - & - & - & $\leq 4.5$ & $\leq 0.1$ & $\leq 5.0$ & - & $\leq 0.75$ & $\leq 5.0$ \\
Powder & 73.52 & 22.36 & 3.32 & 0.17 & 0.01 & - & 0.54 & 0.01 & 0.03 & 0.04 \\
Commercial & & & & & 3.56 & 0.032 & 1.82 & - & 0.50 & 1.66 \\
\hline
\end{tabular}

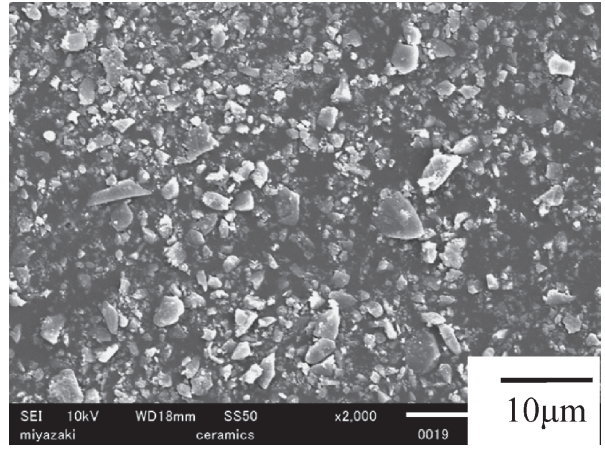

Fig. 1. SEM image of hydrothermally treated soda lime glass powder.

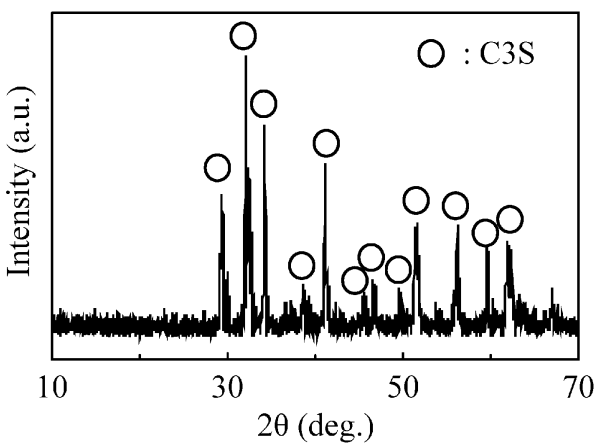

Fig. 2. XRD pattern of the powder resulting from heat treatment of $\mathrm{CaCO}_{3}$ and $\mathrm{SiO}_{2}$ in a molar ratio of $3: 1$ at $1450^{\circ} \mathrm{C}$.

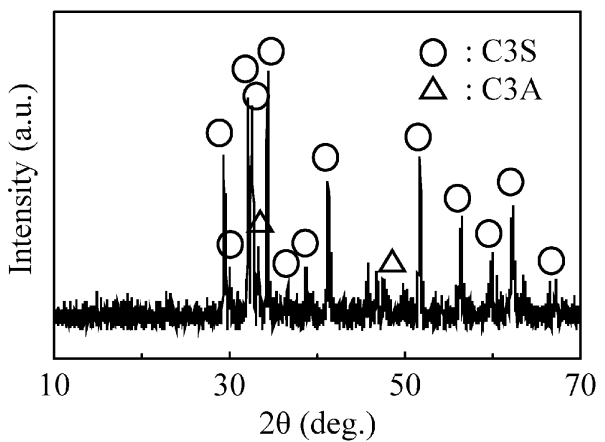

Fig. 3. XRD pattern of the powder resulting from heat treatment of $\mathrm{CaCO}_{3}$ and post-treated glass powder in a weight ratio of $3: 1$ at $1450^{\circ} \mathrm{C}$.

composition of eco-cement in the JIS standard ${ }^{8)}$ is also described in Table 1. The Na content of the resulting powder was $0.03 \mathrm{wt} \%$ because $\mathrm{Na}$ in the post-treated glass was removed from the soda lime glass (source) by the hydrothermal treatment. ${ }^{9}$ ) $\mathrm{The} \mathrm{TiO}_{2}$ content of the powder in the present study was less than $0.04 \%$, and this result is assumed to be attributable to the fact that $\mathrm{TiO}_{2}$ was barely present in the raw soda lime glass. From Table 1, all

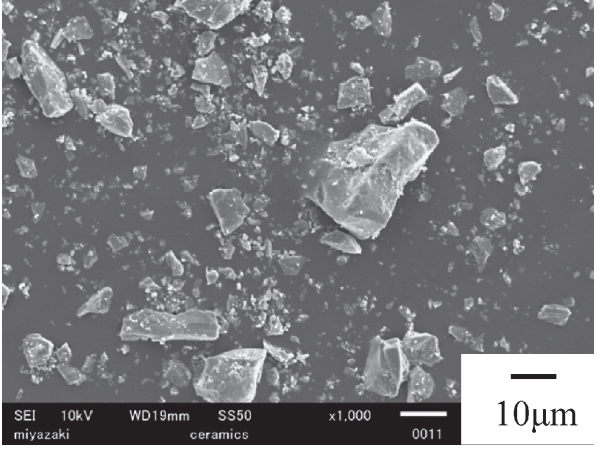

Fig. 4. SEM image of the powder resulting from heat treatment of $\mathrm{CaCO}_{3}$ and post-treated glass powder in a weight ratio of $3: 1$ at $1450^{\circ} \mathrm{C}$.

of the minor components were less than the JIS standard values for eco-cement; ${ }^{8)}$ thus, the recycled cement was confirmed to be successfully synthesized using a soda lime glass source. Hardening tests of the resulting cement have not yet been performed and need to be carried out in the future.

In summary, we have successfully synthesized recycled cements $\mathrm{C} 3 \mathrm{~S}$ and $\mathrm{C} 3 \mathrm{~A}$ with few minor components using hydrothermally treated waste soda lime glass powder; thus, the hydrothermally treated soda lime glass is assumed to be suitable for synthesis of recycled cements.

Acknowledgement Waste soda-lime glass was provided by Cocco Co., Ltd. and we appreciate the sample provision.

\section{References}

1) Recycle data book, Japan Environmental Management Association for Industry (2013) 16

2) M. Terro, Build. Environ., 41, 633-639 (2006).

3) N. Schwarz, H. Cam and N. Neithalath, Cement Concr. Compos., 30, 486-496 (2008).

4) R. Idir, M. Cyr and A. T-Hamou, Cement Concr. Compos., 33, 19-29 (2011)

5) S. Sano, M. Ichikawa, T. Tamashige, T. Matsuto and N. Tanaka, J. Jpn. Soc. Mater. Cycles Waste Manage., 13, 131140 (2002).

6) K. Sudo, H. Harada and T. Takahashi, Ceramics, 34, 349-353 (1999).

7) Y. Masuda, T. Tochigi and Y. Nagashio, Concr. J., 46, 3-9 (2008).

8) JIS R5214:2009.

9) S. Yoshida, H. Miyazaki, S. Sugahara, Y. Seike, H. Suzuki and T. Ota, J. Jpn. Soc. Mater. Cycles Waste Manage., 25, 84-88 (2015).

10) K. Sekino, Inorg. Mater, 4, 483-490 (1997).

11) E. Sakai, K. Raina, K. Asaga, S. Goto and R. Kondo, Cem. Concr. Res., 10, 311-319 (1980).

12) http://www.taiheiyo-cement.co.jp/service_product/cement/pdf/ ecocement_v3.pdf, Taiheiyo-cement pamphlet (2011). 